\title{
HEPATIC AND BIOCHEMICAL REPERCUSSIONS OF A POLYUNSATURATED FAT-RICH HYPERCALORIC AND HYPERLIPIDIC DIET IN WISTAR RATS
}

\author{
Idália M. B. BURLAMAQUI'1 Conceição A. DORNELAS², José Telmo VALENÇA Jr², \\ Francisco J. C. MESQUITA ${ }^{3}$, Lara B. VERAS ${ }^{4}$ and Lusmar Veras RODRIGUES ${ }^{2}$
}

\begin{abstract}
Context - Non-alcoholic fatty liver disease is characterized by lipid deposits in the hepatocytes and has been associated with obesity, dyslipidemia and type- 2 diabetes. It is considered a hepatic manifestation of the metabolic syndrome, of which the main component is insulin resistance leading to hyperinsulinemia and increased production of inflammatory cytokines. Saturated fat promotes hypertriglyceridemia and hyperinsulinemia, reduces levels of high-density cholesterol and increases levels of low-density cholesterol, while polyunsaturated fat is associated with hypolipidemic, antiinflammatory and imunoregulating action. Objective To evaluate the hepatic and biochemical repercussions of a polyunsaturated fat-rich diet in Wistar rats. Methods - Twenty-two rats were distributed equally in two groups: GI - standard diet (Biobase Bio-tec Ratos e Camundongos ${ }^{\circledR}$ ) providing $3.000 \mathrm{kcal} / \mathrm{kg}$ and GII - hypercaloric and hyperlipidic diet providing $4.250 \mathrm{kcal} / \mathrm{kg}(\omega-6: \omega-3=3: 1)$. The animals were euthanized after 23 weeks of experiment. The weight, biochemical parameters and hepatohistological changes were registered. Results - Findings were submitted to variance analysis with the level of statistical significance at $5 \%$. The average weight did not differ significantly between the groups at baseline $(P=0.711)$, but was greater in Group II by the end of the experiment $(P=0.000)$. The levels of triglycerides $(P=0.039)$, total cholesterol $(P=0.015)$ and HDL $(P=0.005)$ were higher in Group I than in Group II. Macrovesicular steatosis was significantly more common in Group II than in Group I $(P=0.03)$. Conclusion - Hypercaloric and hyperlipidic diet rich in polyunsaturated fat promotes weight gain and favors the development of hepatic steatosis while reducing serum levels of triglycerides, total cholesterol and HDL.
\end{abstract}

HEADINGS - Fatty liver. Obesity. Dyslipidemias. Diabetes mellitus, type 2. Rats.

\section{INTRODUCTION}

A fat-rich diet is a risk factor for obesity ${ }^{(16)}$. Extensive research has shown that dietary fat affects a range of metabolic functions, depending on the quantity and composition of fatty acids ${ }^{(9)}$. Diets rich in polyunsaturated fat (PUFA), especially $\omega-3$ and $\omega-9$, are associated with hypolipidemic, antiinflammatory and imunoregulating action. On the other hand, saturated fats and trans fats are known to promote hypertriglyceridemia and hyperinsulinemia, reduce levels of high-density cholesterol (HDL) and increase levels of low-density cholesterol (LDL) ${ }^{(18)}$.

Non-alcoholic fatty liver disease (NAFLD) is the most common type of chronic liver injury in many countries $^{(3,13)}$. Manifestations range from simple steatosis to non-alcoholic steatohepatitis (NASH) to fibrosis, cirrhosis and hepatocellular carcinoma ${ }^{(27)}$. The prevalence of NAFLD, which is currently $15 \%-40 \%$ among Western populations and 9\%-40\% among Asian populations ${ }^{(14)}$, has increased dramatically over the past 15 years, mostly due to its association with the world's two largest current epidemics: obesity and type-2 diabetes mellitus (DM2) (1).

Current research on nutritional change is revealing the important role played by NAFLD in metabolic and cardiovascular complications. NAFLD is considered a hepatic manifestation of the metabolic syndrome, of which the main component is insulin resistance followed by hiperinsulinemia ${ }^{(4,19,25,32)}$ and is characterized by increased uptake, synthesis and accumulation of fatty acids in the hepatocytes, leading to lipogenesis and fatty liver ${ }^{(3)}$. In addition, mitochondrial oxidation defects can cause the fatty acid synthesis to increase to the detriment of triacylglycerol secretion, thereby contributing to hepatic steatosis ${ }^{(30)}$. Hyperinsulinemia

\footnotetext{
This work was performed in the Surgical Department, Federal University of Ceará Medical School, Fortaleza, CE, Brazil.

1 Department of Surgery, Federal University of Ceará; ${ }^{2}$ Department of Pathology and Forensic Medicine. Federal University of Ceará; ${ }^{3}$ School of Medicine, Federal University of Ceará, Fortaleza, CE, Brazil; ${ }^{4}$ School of Medicine, Medical School, Juazeiro do Norte, CE, Brazil.

Correspondence: Dr. Idália Maria Brasil Burlamaqui - Avenida Beira Mar, 3680 - apt. 2001 - Meireles - 60465-121 - Foratleza, CE, Brasil. E-mail: idaliaburlamaqui87@
} hotmail.com 
Burlamaqui IMB, Dornelas CA, Valença Jr JT, Mesquita FJC, Veras LB, Rodrigues LV. Hepatic and biochemical repercussions of a polyunsaturated fat-rich hypercaloric and hyperlipidic diet in wistar rats

also induces oxidative stress with the consequent peroxidation of lipids in the hepatocyte membrane and production of cytokines, especially tumor necrosis factor-alpha $(\mathrm{TNF}-\alpha)^{(3,36)}$.

Recent studies have shown that the adipose tissue secretes not only inflammatory cytokines such as interleukin-6 (IL-6) and TNF- $\alpha$, but also adiponectin-an, insulin-sensitizing and antiinflammatory adipocytokine with multiple beneficial effects on the clinical complications of obesity ${ }^{(24)}$. The hepatoprotective action of adiponectin has been described in several clinical and experimental studies. Low serum levels of adiponectin in obese humans constitute an independent risk factor for NAFLD, including hepatic dysfunction of variable severity ${ }^{(39)}$. Thus, in one study, patients with NASH experienced a reduction of over $50 \%$ in adiponectin levels compared to normals ${ }^{(22)}$. Adiponectin levels are reported to decline by $20 \%-40 \%$ during the transition from simple steatosis to steatohepatitis ${ }^{(22,37)}$. In patients with NASH, very low levels of adiponectin have been associated with severe inflammation, suggesting that adiponectin deficiency is an important risk factor for the development of steatosis, steatohepatitis and other forms of liver damage ${ }^{(5)}$.

Since hypercaloric and hyperlipidic diets can induce liver damage, dyslipidemia and DM2, it may be hypothesized that PUFA-rich diets (containing $\omega-3$ and $\omega-9$ ) offer cardiovascular, hepatic and metabolic protection. Thus, the present study was designed to evaluate the hepatic and biochemical repercussions of a polyunsaturated fat-rich, hypercaloric and hyperlipidic diet in Wistar rats.

\section{METHODS}

\section{Animals and diets}

The study was previously approved by the Federal University of Ceará (UFC), Fortaleza, CE, Brazil, Ethics Committee for Animal Research (CEPA/UFC) under protocol \#11/06 and was conducted according to the International Guiding Principles for Biomedical Research Involving Animals (CIOMS, 1985).

Twenty-two, 180-250 g, 8-week-old male Wistar rats (Rattus norvegicus albinus, Mammalia, Rodentia, Muridae) supplied by the UFC laboratory animal facility were used in the experiments. During the adaptation period, the rats were dewormed with pyrantel pamoate and oxantel pamoate $\left(\right.$ Basken $\left.^{\circledR}\right)$ at $1 \mathrm{~mL} / \mathrm{kg}$. The animals were randomly assigned to two groups at 8 weeks of life, accommodated in individual cages and euthanized in the 23rd week of the experiment. All animals had access to food and water ad libitum.

Group I (GI): Control group of 11 animals receiving standard diet. The diet (Biobase Bio-tec Ratos e Camundongos ${ }^{\mathbb{B}}$ ) provided a total of $3.000 \mathrm{kcal} / \mathrm{kg}$ (Tables 1 and 2).
TABLE 2. Lipid profile and ratios between $\omega-3, \omega-6$ and $\omega-9$ fatty acids in standard diet and hypercaloric and hyperlipidic diet

\begin{tabular}{lcc}
\hline Type of fat & Standard diet & Hyperlipidic diet \\
\hline Polyunsaturated & $54 \%$ & $19 \%$ \\
Monounsaturated & $24 \%$ & $29 \%$ \\
Saturated & $15 \%$ & $6 \%$ \\
$\omega 9 / \omega 6$ & $0.4: 1$ & $1.5: 1$ \\
$\omega 6 / \omega 3$ & $8: 1$ & $3: 1$ \\
Polyunsaturated/saturated & $5.2: 1>60 \% \omega-6$ & $7.6: 1>50 \% \omega-9$ \\
$\% \omega-6$ and 9 & & \\
\hline
\end{tabular}

Group II (GII): Treatment group of 11 animals receiving a hypercaloric and hyperlipidic diet. The diet consisted of $15 \mathrm{~g}$ standard diet $+20 \mathrm{~g}$ Nutri Diabetic ${ }^{\circledR}+5 \mathrm{~mL}$ canola oil and was rich in polyunsaturated fat and omega fatty acids, providing a total of $4.250 \mathrm{kcal} / \mathrm{kg}$ (Tables 2 and 3).

\section{Euthanasia and collection of blood and liver samples}

Following anesthesia by intraperitoneal injection of $80 \mathrm{mg} / \mathrm{kg}$ ketamine and $8 \mathrm{mg} / \mathrm{kg}$ xylazine, the animals were placed in dorsal decubitus on a wooden board with all four limbs immobilized and submitted to laparotomy by xyphopubic median incision and exposure of the abdominal cavity. Blood was collected from the abdominal aorta and tested biochemically for glycemia, uric acid, aspartate transaminase (AST), alanine transaminase (ALT), gammaglutamyl transpeptidase (GGT), triglycerides, HDL and total cholesterol. Subsequently, a $1-\mathrm{cm}^{3}$ liver fragment retrieved by left hepatectomy was submitted to anatomopathological analysis at the Department of Pathology and Legal Medicine (School of Medicine, UFC). Finally, euthanasia was induced by aortic bleeding.

\section{Histological study of liver samples}

Following fixation in 10\% formaldehyde, the liver samples were embedded in paraffin and stained with hematoxylineosin (H-E). Hepatic steatosis was classified in four grades based on the histological findings (Table 4$)^{(8)}$.

\section{Statistical analysis}

The statistical analysis was performed with the software SPSS v.16.0 for Windows ${ }^{\circledR}$. All laboratory variables were normal with regard to the distribution of variance homogeneity. Average values were analyzed with Student's $t$ test. Fisher's exact test was used to verify the association between diet type and the presence of hepatic steatosis. The level of statistical significance was set at $5 \%(P<0.05)$.

TABLE 1. Composition of standard (normoglycidic, hypolipidic and high-protein) diet (Biobase Biotec ${ }^{\circledR}$ Ratos e Camundongos)

\begin{tabular}{lccccc}
\hline Food & Amount $(\mathrm{g})$ & Kcal & Carbohydrate $(\mathrm{g})$ & Protein $(\mathrm{g})$ & Lipid $(\mathrm{g})$ \\
\hline Biobase Bio-tec & $(10$ & 120 & 17.6 & 8.8 & 1.6 \\
TOTAL & 40 & 120 & 17.6 & 8.8 & 1.6 \\
Total distribution of calories & & & 70.4 & 35.2 & 14.4 \\
Calories (\%) & & & $58.66 \%$ & $29.34 \%$ & $12.00 \%$ \\
\hline
\end{tabular}


TABLE 3. Composition of hypercaloric and hyperlipidic diet

\begin{tabular}{|c|c|c|c|c|c|}
\hline Food & Amount (g) & Kcal & Carbohydrate (g) & Protein $(\mathrm{g})$ & Lipid (g) \\
\hline Biobase Bio-tec ${ }^{\circledR}$ & 15 & 45 & 6.6 & 3.3 & 0.6 \\
\hline Nutri Diabetic ${ }^{\circledast}$ & 20 & 80 & 11 & 3.2 & 2.6 \\
\hline Canola oil & 5 & 45 & 0 & 0 & 5 \\
\hline TOTAL & 40 & 170 & 16.6 & 6.5 & 8.2 \\
\hline Total distribution of calories & & & 70.4 & 26 & 73.8 \\
\hline Calories $(\%)$ & & & $41.36 \%$ & $15.28 \%$ & $43.36 \%$ \\
\hline
\end{tabular}

TABLE 4. Classification of steatosis

\begin{tabular}{ll}
\hline Grade & Macrovesicular steatosis \\
\hline 0 & Absent \\
1 & Mild (>0\% to $33 \%)$ \\
2 & Moderate $(>33 \%$ to $66 \%)$ \\
3 & Severe $(>66 \%)$ \\
\hline
\end{tabular}

\section{RESULTS}

\section{Biochemical analysis}

The tests revealed statistically significant differences between Group I and Group II with regard to the levels of triglycerides $(P=0.039)$, total cholesterol $(P=0.015)$ and HDL $(P=0.005)$ (Table 5).

\section{Weight distribution}

The average weight did not differ significantly between the groups at baseline $(P=0.711)$, but was greater in Group II by the end of the experiment $(P=0.000)$ (Table 6$)$.

\section{Anatomopathological findings}

The number of animals with macrovesicular steatosis was significantly greater in Group II (HD) than in Group I ( $P=$ 0.03) (Table 7; Figures 1 and 2).

TABLE 5. Biochemical findings for Groups I and II

\begin{tabular}{lccc}
\hline Laboratory Test & $\begin{array}{c}\text { Group I } \\
\text { Average } \pm \text { standard diet }\end{array}$ & $\begin{array}{c}\text { Group II } \\
\text { Average } \pm \text { standard diet }\end{array}$ & P-value \\
\hline Glycemia $(\mathrm{mg} / \mathrm{dL})$ & $136.09 \pm 28.01$ & $150.00 \pm 24.91$ & 0.261 \\
Uric Acid (mg/dL) & $1.39 \pm 0.36$ & $1.15 \pm 0.36$ & 0.165 \\
AST (U/L) & $87.54 \pm 35.27$ & $66.64 \pm 19.10$ & 0.129 \\
ALT (U/L) & $42.31 \pm 12.39$ & $33.36 \pm 11.71$ & 0.117 \\
GGT (U/L) & $0.40 \pm 0.33$ & $0.50 \pm 0.68$ & 0.700 \\
CRP & $0.5 \pm 0.00$ & $0.5 \pm 0.00$ & 1.000 \\
Triglycerides (mg/dL) & $80.09 \pm 22.36$ & $59.44 \pm 18.10$ & $0.039 *$ \\
Total cholesterol (mg/dL) & $70.91 \pm 18.08$ & $53.44 \pm 8.12$ & $0.015^{*}$ \\
HDL (mg/dL) & $62.55 \pm 11.75$ & $48.22 \pm 7.25$ & $0.005^{*}$ \\
\hline
\end{tabular}

* Statistically significant difference $(P<0.05)$

TABLE 6. Weight distribution (g) of Group I and Group II at baseline and by the end of the experiment

\begin{tabular}{lccc}
\hline \multirow{2}{*}{ Group } & \multirow{2}{*}{} & \multicolumn{2}{c}{ Average $(\mathrm{g}) \pm$ Standard deviation } \\
\cline { 3 - 4 } & & Baseline & Final \\
\hline I & 11 & $200.8 \pm 11.1$ & $385.0 \pm 16.4$ \\
II & 11 & $203.4 \pm 17.0$ & $431.6 \pm 20.1$ \\
\hline
\end{tabular}

* By the end of the experiment the average weight was greater in Group II than in Group I $(P=0.000)$
TABLE 7. Fisher's exact test

\begin{tabular}{lcc}
\hline Group & Absence of steatosis & Presence of steatosis \\
\hline I & $9(81.8 \%)$ & $2(18.2 \%)$ \\
II & $3(27.3 \%)$ & $8(72.7 \%)^{*}$ \\
\hline
\end{tabular}
$P=0.03$ 


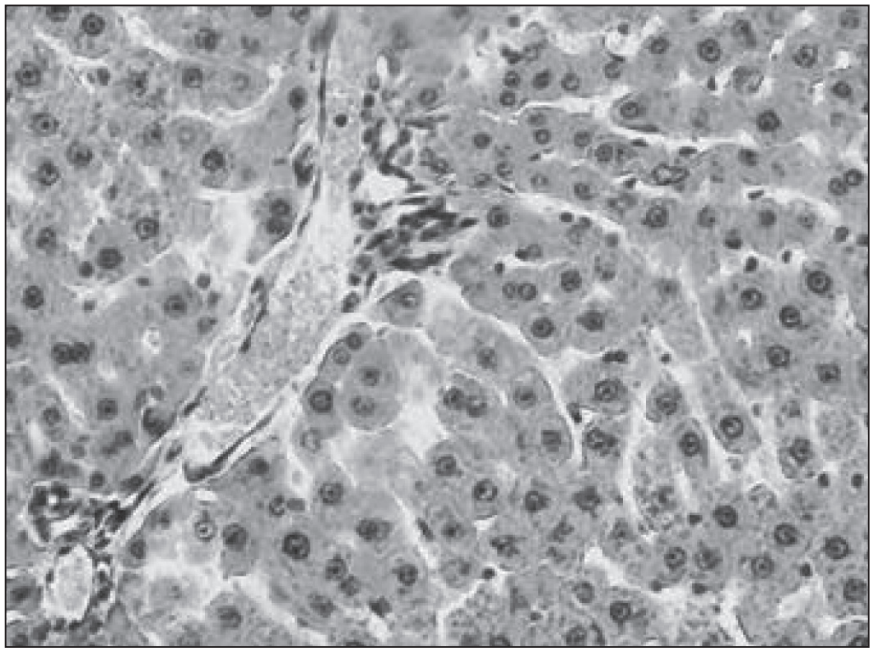

FIGURE 1. Histopathological section of liver tissue from rat 2, Group I, showing macrovesicular steatosis grade $0(\mathrm{H}-\mathrm{E} ; 400 \mathrm{X})$

\section{DISCUSSION}

Recent research has drawn attention to the association between NAFLD and a number of health problems, including obesity, dyslipidemia, type-2 diabetes and cancer. The pathogenesis of NAFLD is not completely understood, but insulin resistance, oxidative stress and inflammation all play an important role in the development and progression of the disorder ${ }^{(23,26,29)}$. In addition, unusually high levels of circulating free fatty acids have been correlated with NAFLD severity ${ }^{(15)}$.

Changes in dietary fat composition can affect metabolic functions and lead to changes in body weight and composition ${ }^{(28)}$. In the present study, animals fed with a PUFA-rich diet displayed significant weight gain, as observed in other studies ${ }^{(18)}$. PUFA-rich diets have been associated with reduced food intake ${ }^{(17)}$, probably, because animals receiving high-fat diets, as opposed to high-calorie diets, require less energy for lipid deposition ${ }^{(34)}$.

In addition, epidemiological studies have found an inverse relation between the incidence of cardiovascular disease and the intake of $\omega$-3 PUFA ${ }^{(21,31)}$.

The effect of different types of PUFA on body adiposity has been the object of much controversy. PUFA-rich diets with large amounts of $\omega-3$ and $\omega-6$ were recently reported, respectively, to reduce lipolysis and increase dietary lipid uptake in the adipose tissue. Both fatty acids caused changes in liver metabolism and favored lipid deposition ${ }^{(17)}$.

The levels of triglycerides, total cholesterol and HDL were lower in animals receiving the enhanced diet (Table 5). Positive effects of $\omega-3$ fatty acids on the reduction of triglycerides and total cholesterol serum levels have been reported in several other studies using animal or human models ${ }^{(2,33)}$. Omega-3 fatty acids can inhibit the activity of diacylglycerol

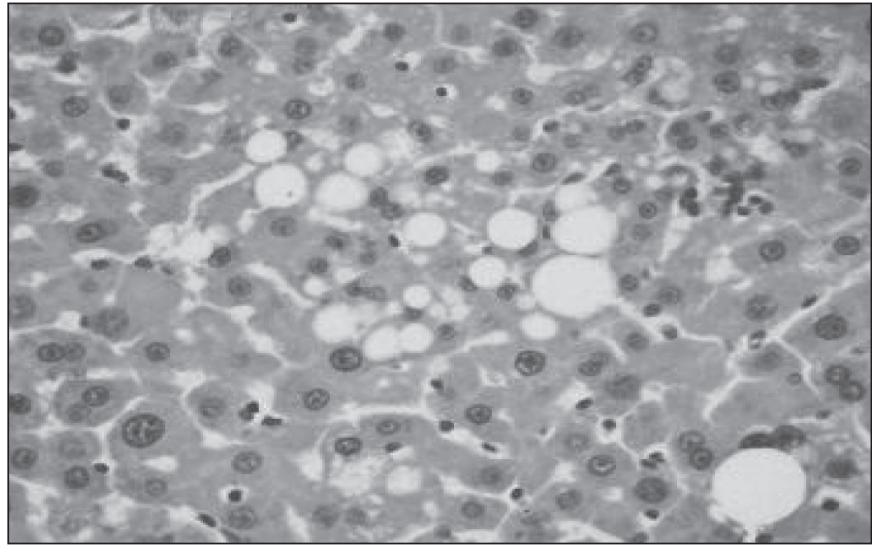

FIGURE 2. Histopathological section of liver tissue from rat 9, Group II, showing macrovesicular steatosis grade 1 (H-E; 400X)

acyltransferase-a catalyst of triglyceride synthesis ${ }^{(35)}$. Rats fed with $\omega-3$ fatty acid have been shown to have reduced total cholesterol serum levels due to increased biliary cholesterol excretion $^{(6)}$.

C-reactive protein (CRP) is produced in the liver. However, high CRP serum levels are considered a non-specific indicator of inflammation. Contrary to expectations, all the animals in our study had CRP levels below $0.5 \mathrm{mg} / \mathrm{dL}$. Higher levels were expected, especially in Group II, due to the increased intake of calories and fat, greater weight and consequently greater probability of inflammation. The low CRP levels observed may be attributed to the antiinflammatory action of $\omega-3$ fatty $\operatorname{acids}^{(38)}$.

The study diet was expected to produce a protective effect on the liver, but the histological analysis showed steatosis to be statistically more predominant in Group II than in Group I (Table 7). Possibly, the lower adiponectin levels in the significantly heavier animals of Group II may not have been sufficiently insulin-sensitizing and antiinflammatory to prevent the development of NAFLD.

Studies using rats have shown that lipid deposition in the liver is related to oxidative stress and that lipid peroxidation increases in proportion to the severity of hepatic steatosis ${ }^{(12)}$. This may explain why hepatic steatosis was observed in a much greater proportion of the animals receiving hypercaloric and hyperlipidic food $(72.7 \%)$ than in animals receiving the standard diet $(18.2 \%)$. In other words, the risk of steatosis was greater in the treatment group because lipid peroxidation favors the development of NASH ${ }^{(11,23)}$.

Interestingly, though hepatic steatosis is often associated with slightly or moderately increased levels of ALT and AST ${ }^{(10)}$, both parameters remained normal in Group II.

Confirming the findings of other researchers ${ }^{(7,20)}$, our study shows that although diets rich in polyunsaturated fatty acids improve the serum lipid profile, they can also cause undesirable changes in hepatic metabolism and lipid deposition. 


\section{CONCLUSIONS}

These results show that a hypercaloric and hyperlipidic diet rich in polyunsaturated fat promotes weight gain and favors the development of hepatic steatosis while reducing serum levels of triglycerides, total cholesterol and HDL.

\section{ACKNOWLEDGEMENTS}

This study was supported by the following Brazilian agencies: the National Council for Scientific and Technological Development (CNPq); Surgical Department, Federal University of Ceará Medical School; and the Experimental Surgery Laboratory (LABCEX), Federal University of Ceará, Medical School.

Burlamaqui IMB, Dornelas CA, Valença Jr JT, Mesquita FJC, Veras LB, Rodrigues LV. Repercussões hepáticas e bioquímicas da dieta hipercalórica e hiperlipídica rica em gordura poliinsaturada em ratos Wistar. Arq Gastroenterol. 2011;48(2):153-8.

RESUMO - Contexto - A doença hepática gordurosa não-alcoólica caracteriza-se por depósito de lipídios nos hepatócitos. Desperta grande interesse por sua associação com obesidade, dislipidemias e diabetes mellitus tipo 2. É considerada a manifestação hepática da síndrome metabólica, cujo principal componente é a resistência à insulina, com consequente hiperinsulinemia e produção aumentada de citocinas inflamatórias. Dietas ricas em gorduras saturadas promovem hipertrigliceridemia, diminuição do colesterol de alta densidade, aumento do colesterol de baixa densidade e hiperinsulinemia, enquanto dietas ricas em gordura poliinsaturada podem apresentar efeitos hipolipidêmicos, antiinflamatórios e imunorreguladores. Objetivo - Investigar as repercussões hepáticas e bioquímicas da dieta rica em gordura poliinsaturada em ratos Wistar. Métodos - Os animais (22) foram distribuídos nos grupos GI-dieta padrão (Biobase Bio-tec Ratos e Camundongos ${ }^{\circledR}$ ) com 3000 kcal/kg e GII-dieta hipercalórica e hiperlipídica, com $4250 \mathrm{kcal} / \mathrm{kg}$, relação $\omega-6: \omega-3=3: 1$. Foram mortos após 23 semanas de administração das dietas. Avaliaram-se peso, exames bioquímicos e alterações histológicas do fígado. Resultados - Foram utilizados testes de análise de variância com nível de significância de $5 \%(P<0,05)$. Não houve diferença significante na média de peso entre os grupos $(P=0,711)$ no início, entretanto GII apresentou maior média que GI ao final do experimento $(P=0,000)$. GI mostrou níveis significantemente mais elevados de triglicerídeos $(P=0,03)$, colesterol total $(P=0,039)$ e HDL $(P=0,015)$ do que GII. O GII apresentou maior média de esteatose macrovesicular do que GI $(P=0,005)$. Conclusão - A dieta hipercalórica e hiperlipídica, rica em gordura poliinsaturada, promove esteatose hepática e incremento de peso, contudo reduz os níveis séricos de triglicerídeos, colesterol total e HDL.

DESCRITORES - Fígado gorduroso. Obesidade. Dislipidemias. Diabetes mellitus tipo 2. Ratos.

\section{REFERENCES}

1. Adams LA, Angulo P. Recent concepts in non-alcoholic fatty liver disease. Diabet Med. 2005;22:1129-33.

2. Aguilera AA, Díaz GH, Barcelata ML, Guerrero OA, Ros RM. Effects of fish oil on hypertension, plasma lipids and tumor necrosis factor- $\alpha$ in rats with sucroseinduced metabolic syndrome. J Nutr Biochem. 2004;15:350-7.

3. Angulo P. Nonalcoholic fatty liver disease. N Engl J Med. 2002;346:1221-31.

4. Arrospide MT. Hígado graso no alcohólico. Rev Gastroenterol Peru. 2003; 23:49-57.

5. Aygun C, Senturk O, Hulagu S, Uraz S, Celebi A, Konduk, T, Mutlu B, Canturk Z. Serum levels of hepatoprotective peptide adiponectina in non-alcoholic fatty liver disease. Eur J Gastroenterol Hepatol. 2006;18:175-80.

6. Balasubramaniam S, Simons LA, Chang S, Hickie JB. Reduction in plasma cholesterol and increase in biliary cholesterol by a diet rich in $n-3$ fatty acids in the rat. J Lipid Res. 1985;26:684-9.

7. Brown AM, Baker PW, Gibbons GF. Changes in fatty acid metabolism in rat hepatocytes in response to dietary n-3 fatty acids are associated with changes in the intracellular metabolism and secretion of apoprotein B-48. Lipid Res. 1997;38:469-81.

8. Brunt EM, Janney CG, Di Bisceglie AM, Neuschwander-Tetri BA, Bacon BR Non-alcoholic steatohepatitis: a proposal for grading and staging the histological lesions. Am J Gastroenterol. 1999;94:2467-74.

9. Campos FG, Logullo Waitzberg AG, Kiss DR, Waitzberg DL, Habr-Gama A Gama-Rodrigues J. Diet and colorectal cancer: current evidence for etiology and prevention. Nutr Hosp. 2005;20:18-25.

10. Carvalheira JB, Saad MJ. [Insulin resistance/hiperinsulinemia associated diseases not included in the metabolic syndrome]. Arq Bras Endocrinol Metab. 2006;50:360-

11. Day CP, James OF. Steatohepatitis a tale of two "hits"? Gastroenterology. 1998;114:842-5.

12. Diehl AM. Lessons from animal models of NASH. Hepatol Res. 2005;33: 138-44.
13. Farrell GC. Non-alcoholic steatohepatitis: what is it, and why is it important in the Asia-Pacific region? J Gastroenterol Hepatol. 2003;18:124-38.

14. Farrell GC, Larter CZ. Nonalcoholic fatty liver disease: from steatosis to cirrhosis. Hepatology. 2006;43:s99-112.

15. Feldstein AE, Werneburg NW, Canbay A, Guicciardi ME, Bronk SF, Rydzewsky R, Burgart LJ, Gores, GJ. Free fatty acids promote hepatic lipotoxicity by stimulating TNF-alpha expression via a lysosomal pathway. Hepatology. 2004;40:185-94.

16. Feoli AM, Roehrig C, Rotta LN, Kruger AH, Souza KB, Kessler AM, Renz SV, Brusque AM, Souza DO, Perry ML. Serum and liver lipids in rats and chicks fed with diets containing different oils. Nutrition. 2003;19:789-93.

17. Gaíva MH, Couto RC, Oyama LM, Couto GE, Silveria VL, Roberio EB, Nascimento CM. Polyunsaturated fatty acids-rich diets: effect on adipose tissue metabolism in rats. Br J Nutr. 2001;86:371-7.

18. Gaíva MH, Couto RC, Oyama LM, Couto GE, Silveira VL, Ribeiro EB, Nascimento CM. Diets rich in polyunsaturated fatty acids: effect on hepatic metabolism in rats. Nutrition. 2003;19:144-9.

19. Guidorizzi de Siqueira AC, Cotrim HP, Rocha R, Carvalho FM, Freitas LA, Barreto D, Gouveia L, Landeiro L. Non-alcoholic fatty liver disease and insulin resistance: importance of risk factors and histological spectrum. Eur J Gastroenterol Hepatol. 2005; 17:837-41

20. Hill JO, Peters JC, Lin D, Yakubu F, Greene H, Swift L. Lipid accumulation and body fat distributions is influenced by type of dietary fat fed to rats. Int $\mathbf{J}$ Obes Relat Metab Disord. 1993;17:223-36.

21. Hooper L, Summerbell CD, Higgins JP, Thompson RL, Capps NE, Smith GD, Riemersma RA, Ebrahim S. Dietary fat intake and prevention of cardiovascular disease: systematic review. BMJ. 2001;322:757-63.

22. Hui JM, Hodge A, Farrell GC, Kench JG, Kriketors A, George J. Beyond insulin resistance in NASH: TNF-alpha or adiponectin? Hepatology. 2004;40:46-54.

23. Ito M, Suzuki J, Sasaki M, Watanabe K, Tsujioka S, Takahashi Y, Gomori A, Hirose H, Ishihara A, Iwaasa H, Kanatani A. Development of nonalcoholic steatohepatitis model through combination of high-fat diet and tetracycline with morbid obesity in mice. Hepatol Res. 2006;34:92-8.

24. Kamada Y, Takehara T, Hayashi N. Adipocytokines and liver disease. J Gastroenterol. 2008;43:811-22. 
25. Kang H, Greenson JK, Omo JT, Chao C, Peterman D, Anderson L, Foess-Wood, L, Sherbondy, MA, Conjeevaram, HS. Metabolic syndrome is associated with greater histologic severity, higher carbohydrate, and lower fat diet in patients with NAFLD. Am J Gastroenterol. 2006;101:2247-53.

26. Machado M, Cortez-Pinto $H$. Non-alcoholic fatty liver disease and insulin resistance. Eur J Gastroenterol Hepatol. 2005;17:823-6.

27. Matteoni CA, Younossi ZM, Graramlich T, Boparai N, Liu YC, Mc-Cullough AJ. Nonalcoholic fatty liver disease: a spectrum of clinical and pathological severity. Gastroenterology. 1999;116:1413-9.

28. Mauler B, Dubben S, Pawelzik M, Pawelzik D, Weigle DS, Kratz M. Hypercaloric diets differing in fat composition have similar effects on serum leptin and weight gain in female subjects with anorexia nervosa. Nutr Res. 2009;29:1-7.

29. Mehta K, Van Thiel DH, Shah N, Mobarhan S. Nonalcoholic fatty liver disease: pathogenesis and the role of antioxidants. Nutr Rev. 2002;60:289-93.

30. Minehira K, Young SG, Villanueva CJ, Yetukuri L, Oresic M, Hellerstein MK, Farese RV Jr, Horton, JD, Preitner F, Thorens B, Tappy L. Blocking VLDL secretion causes hepatic steatosis but does not affect peripheral lipid stores or insulin sensitivity in mice. J Lipid Res. 2008;49:2038-44.

31. Mori TA, Beilin LJ. Long-chain omega 3 fatty acids, blood lipids and cardiovascular risk reduction. Curr Opin Lipidol. 2001;12:11-7.

32. Moscatiello S, Manini R, Marchesini G. Diabetes and liver disease: an ominous association. Nutr Metab Cardiovasc Dis. 2007;17:63-70.
33. Oh R. Pratical applications of fish oil (Omega-3 fatty acids) in primary care. J Am Board Fam Pract. 2005;18:28-36.

34. Oudart H, Groscolas R, Calgari C, Nibbelink M, Leray C, Le Maho Y, Malan A. Brown fat thermogenesis in rats fed high-fat diets enriched with n-3 ployunsaturated fatty acids. Int J Obes Metab Disord. 1997;21:955-62.

35. Rustan AC, Nossen JO, Christiansen EN, Drevon CA. Eicosapentaenoic acid reduces hepatic synthesis and secretion of triacylglicerol by decreasing the activity of acyl-coenzyme A:1,2-diacylglycerol acyltransferase. J Lipid Res. 1988;29:1417-26.

36. Sass DA, Chang P, Chopra KB. Nonalcoholic fatty liver disease: a clinical review Dig Dis Sci. 2005;50:171-80.

37. Shimada M, Kawahara H, Ozaki K, Fukura M, Yano H, Tsuchishima M, Tsutsum M, Takase S. Usefulness of a combined evaluation of the serum adiponectin level, HOMA-IR, and serum type IV collagen $7 \mathrm{~S}$ level to predict the early stage of non-alcoholic steatohepatitis. Am J Gastroenterol. 2007;102:1931-8.

38. Teitelbaum JE, Allan Walker WA. Review: the hole of omega 3 fatty acids in intestinal inflammation. J Nutr Biochem. 2001;12:21-32.

39. Tilg H, Hotamisligil GS. Nonalcoholic fatty liver disease: cytokine-adipokine interplay and regulation of insulin resistance. Gastroenterology. 2006;131:934-45.

Received 5/11/2010

Accepted 25/11/2010 